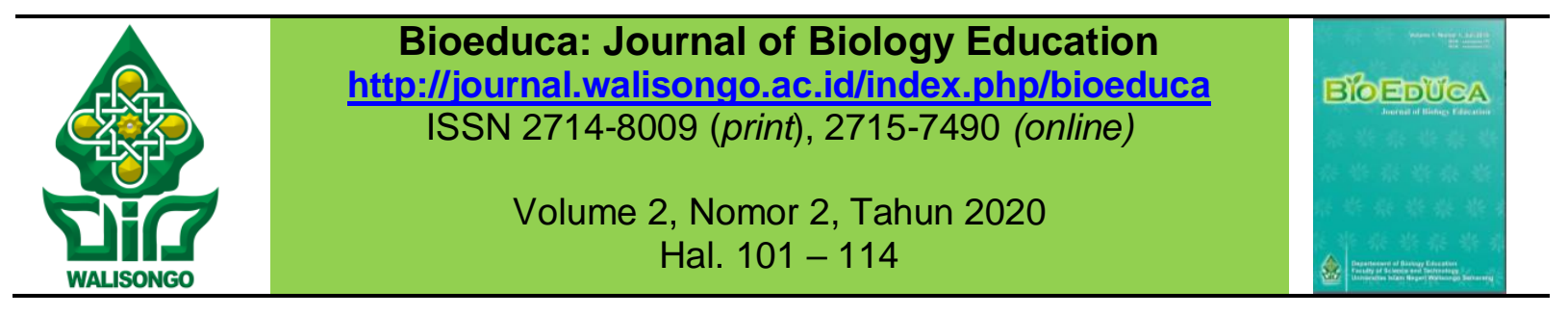

\title{
Kunci Tadabbbur dan Integrasi Al-Qur'an dalam Pembelajaran Biologi
}

\author{
Mujahidin Ahmad $^{1 *}$, Eko Budi Minarno ${ }^{2}$, Suyono ${ }^{3}$ \\ ${ }^{1,2,3}$ Biologi, Universitas Islam Negeri Maulana Malik Ibrahim Malang \\ *Email: mujahidin@bio.uin-malang.ac.id
}

\begin{tabular}{|c|c|}
\hline Informasi Artikel & ABSTRAK \\
\hline $\begin{array}{l}\text { Submit: } 02-09-2020 \\
\text { Diterima: } 29-09-2020 \\
\text { Dipublikasikan: } 11-10-2020\end{array}$ & $\begin{array}{l}\text { Islam sebagai agama yang sempurna (din-al kamil) dan universal } \\
\text { (din-asy syamil) selalu menarik dijadikan sebagai sumber } \\
\text { inspirasi pemikiran. Hal ini karena Al-Qur'an tidak hanya } \\
\text { mengatur aspek hubungan manusia dengan tuhannya namun } \\
\text { juga termasuk mengatur hubungannya dengan sesama makhluk. } \\
\text { Upaya pendekatan hubungan antara sains dan al-quran } \\
\text { khusunya biologi adalah sebuah upaya implementasi sains } \\
\text { dalam kehidupan sehari hari terutama sebagai masyarakat yang } \\
\text { religius. Diharapkan dengan adanya pengenalan model baru } \\
\text { dapat memudahkan upaya integrasi Al-Qur'an dalam } \\
\text { pembelajaran biologi. Metode yang digunakan dalam penelitian } \\
\text { ini adalah telaah pustaka. Dalam pembelajaran Biologi, integrasi } \\
\text { Sains-Islam dapat dilakukan dengan tiga macam model } \\
\text { pendekatan yaitu; Model Integrasi Al-Qur'an sebagai Sumber } \\
\text { Inspirasi, Konfirmasi dan Dogma-empiris. Ketiga model } \\
\text { pendekatan dapat dijalankan secara simultan dalam proses } \\
\text { pembelajaran Biologi. } \\
\text { Kata kunci: al-qur'an; dogma empiris; model integrasi; inspirasi; } \\
\text { konfirmasi. }\end{array}$ \\
\hline Penerbit & ABSTRACT \\
\hline $\begin{array}{l}\text { Program Studi Pendidikan } \\
\text { Biologi, Fakultas Sains dan } \\
\text { Teknologi, UIN Walisongo } \\
\text { Semarang }\end{array}$ & $\begin{array}{l}\text { Islam as a perfect (din-al-kamil) and universal (din-asy syamil) } \\
\text { religion is always interesting as a source of thought inspiration. } \\
\text { This is because the Al-Qur'an does not only regulate aspects of } \\
\text { the relationship between humans and their gods but also includes } \\
\text { regulating their relationships with fellow beings. The effort to } \\
\text { approach the relationship between science and the al-quran, } \\
\text { especially biology, is an effort to implement science in everyday } \\
\text { life, especially as a religious society. It is hoped that the } \\
\text { introduction of a new model can facilitate efforts to integrate the } \\
\text { Qur'an into biology learning. The method used in this research is } \\
\text { literature review. In Biology learning, the integration of Science- } \\
\text { Islam can be done with three kinds of approaches, namely; The } \\
\text { Integration Model of the Qur'an as a Source of Inspiration, } \\
\text { Confirmation and Dogma-empirical. The three model approaches } \\
\text { can be run simultaneously in the Biology learning process. } \\
\text { Keywords: al-qur'an; empirical-dogma; integration model; } \\
\text { inspiration; confirmation. }\end{array}$ \\
\hline
\end{tabular}

Copyright $\mathcal{O} 2020$, Bioeduca: Journal of Biology Education 


\section{PENDAHULUAN}

Umat islam memiliki kontribusi yang sangat berarti di bidang sains, diantaranya bidang biologi dan ilmu kedokteran. Fakta sejarah membuktikan bahwa di dalam era kekuasaan islam telah melahirkan berbagai Imuwan yang diakui oleh dunia. Sejarah mencatat nama nama seperti; Jabir Ibn Haiyan, al-Kindi, al-Khwarizmi, al-Farghani, al-Razi, Thabit ibn Qurra, al-Battani, Hunain ibn Ishaq, al-Farabi, Ibrahim ibn Sinan, alMasudi, al-Tarabi, Abu ibn Wafa, Ali ibn Abbas, Abu-I-Qasim, Ibn al-Jazzar, al-Biruni, Ibn Sina, Ibn Yunus, al-Karkhi, Ibn al- Haitham, Ali ibn Isa, al-Ghazzali, al-Zarqali, Omar Khayyam, Ibu Rusyd dan banyk lagi lainnya yang karyanya tersebar sangat luas (Faruqi, 2006; Sarton, 1927). Beberapa pihak banyak yang tidak mengetahui bahwasanya mereka bukan hanya ahli di bidang sains tapi meraka juga ahli di bidang agama. Hal tersebut menjadi bukti bahwa ada korelasi antara kecerdasan sains dan spiritual, dan hal itu mampu menghadirkan peradaban emas (Kettani, 1976), studi selama beberapa dekade menunjukkan adanya sinergitas antara al-qur'an dan sains dan semakin menarik untuk terus dikaji (Wahid, 2018). Ilmu sebenarnya universal, Berasal juga dari sumber yang tunggal, yaitu dari Allah, manusia tidak diberi ilmu kecuali sedikit saja (Al-Isra: 85). Karena ilmu (Al-Qur'an dan Sains), qauiyah dan kauniyah bersumber dari Tuhan yang Esa maka tidak akan ditemukan kontradiksi di dalamnya (Hussain, 2019). Sehingga upaya dikotomi tidaklah tepat. Upaya sekuleraisasi agama ini memiliki dampak buruk di dunia pendidikan terutama kaitannya dengan implikasi moral dan sosial (Wahid, 2018; Suryaningsih 2018).

Fakta dunia menunjukan bahwa kemajuan teknologi tidak menjamin kemajuan sebuah peradaban yang menjungjung tinggi etika. Bahkan Para ahli sains menyatakan tentang pentingnya sistem kepercayaan atau believe dalam sains dan pembelajarannya (Faruqi, 2006). Sebagai contoh, diantara kegemilangan peradaban islam; dalam bidang biologi dan zoologi, serta teori evolusi yang sangat terkenal, yang dicetuskan oleh Darwin, sudah sejak lama sebelumnya dicetuskan oleh ilmuwanilmuwan muslim beberapa abad sebelumnya. Malik, Ziermann, dan Diogo (2018) menyebutkan diantara contoh ilmuwan muslim yang memiliki teori-teori dalam ilmu biologi, khususnya evolusi (gambar 1).

Bahkan menurut Qutub (2011) ilmuwan muslim di dunia medis memiliki bukubuku kedokteran untuk dijadikan sebagai rujukan lebih dari 6 abad di sekolah-sekolah kedokteran eropa. Hal ini terjadi krena di masa lampau tidak dikenal pemisahan ilmu; agama dan dunia. Hanya kemudian muncul dikotomi yang membedakan antara ilmu agama dengan ilmu di luar agama yang kemudian diberi sebutan dengan ilmu umum IImu pengetahuan. Padahal pada hakekatnya semua ilmu berasal dari Allah s.w.t. Manusia hanya bersifat menemukan, namun pencipta tetap Allah s.w.t. Kalaupun ada pembagian atau segregasi ilmu, dapat dilakukan dengan cara pembagian skala prioritas, sebagaimana pendapat AI-Ghazzali; IImu yang bersifat Fardhu 'Ain dan IImu yang bersifat Fardhu Kifayah (Fajari, 2016). 
A

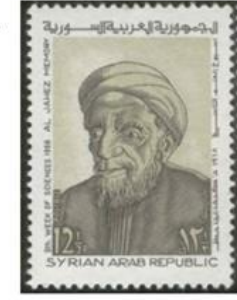

$\mathbf{E}$

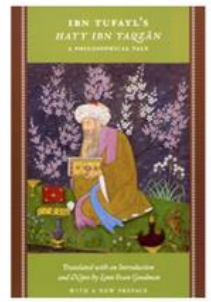

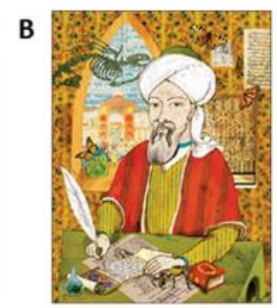

F

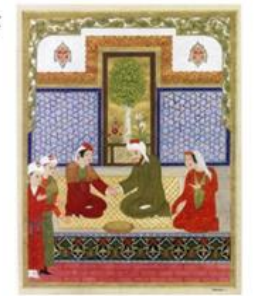

c
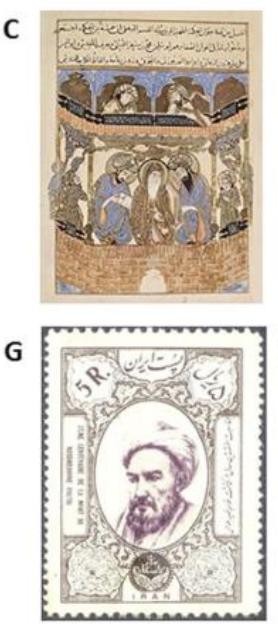
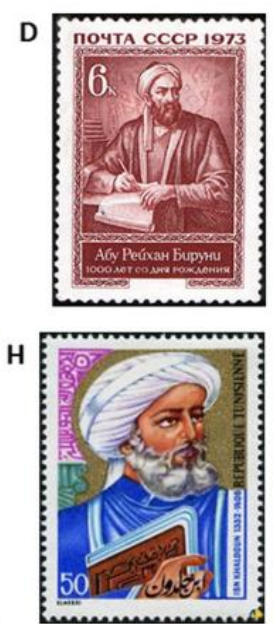

Gambar 1. IImuwan Muslim yang mencetuskan ide tentang evolusi sebelum kelahiran Darwin: (a) al-Jahiz (776-868); (B) Ibn Miskawayh (930-1030); (c) Ikhwan al-Safa (tenth century;); (d) alBeruni (973-1048); (E) Ibn Tufayl (1110-1185); (f) Nidhami Arudi (twelfth century; Muslim Heritage); (g) Tusi (1201-1274); dan (H) Ibn Khaldun (1332-1406).

Pemisahan ilmu agama dengan ilmu-ilmu yang dikenal sebagai ilmu umum, semakin dipertajam dengan pemikiran dalam filsafat ilmu yang mengatakan agama dimulai dari percaya sedangkan ilmu dimulai dari tidak percaya. Hal inilah yang memperkuat anggapan bahwa antara ilmu agama dengan ilmu umum merupakan sesuatu yang tidak dapat ditemukan, mereka berdiri sendiri-sendiri. Seringkali muncul seruan agar jangan mencampur adukkan antara agama dengan ilmu atau ilmu dengan agama, karena mereka berdua berasal dari sesuatu yang berbeda. AM Saefuddin melihat ilmu pengetahuan sebagai sarana untuk mendekatkan diri dengan sang khaliq tanpa memisahkan entitas empirik dan metafisik, ia bersifat holistik dan integral tidak dapat dipisahkan, jika dipisahkan akan terjadi kerancuan dalam mengetahui suatu objek (Fajari, 2016; Zain \& Febriyanto, 2017). Kemunculan ide "Islamisasi ilmu, integrasi ilmu, tidak lepas dari ketimpangan-ketimpangan yang merupakan akibat langsung keterpisahan antara sains dan agama tersebut (Mufid, 2013)

Upaya integrasi islam dan sains (ilmu pengetahuan) sudah banyak dilakukan. oleh para IImuan Muslim seperti Fazlur Rahman, Seyyed Hossein Nasr, Ziauddin Sardar, Ismail Raji' al-Faruqi dan Syekh Muhammad Naquib al-Attas (Muslih, 2014). Di Indonesia sendiri upaya ini terus dikembangkan oleh para ilmuan dan akademisi, diantaranya adalah Am. Saefudin (Desekulerisasi ilmu pengetahuan), Kuntowijoyo (Paradigma Islam sebagai IImu), M. Amin Abdullah (jaring laba-laba keilmuan), dan Imam Suprayogo (pohon ilmu), Azyumiardi Azra (reintegrasi ilmu qauliyah dan kauniyah) (Hidayat, 2014; Wardani, 2018). Pada kesempatan ini penulis mencoba menawarkan model integrasi alternatif yang diharapkan lebih praktis dalam implementasi di dunia pendidikan sehingga menjadi sarana pembuka pintu tadabbur ayat-ayat Allah khususnya di bidang biologi menjadi lebih mudah.

\section{METODE PENELITIAN}

Metode yang digunakan dalam penelitian ini adalah telaah pustaka (literature review) dari; textbook, jurnal, artikel dan website yang terkait dengan judul tulisan. 
Hasil telaah pustaka diolah secara mendalam oleh penulis untuk menemukan model alternatif yang dapat direkomendasikan dalam pendekatan integrasi islam dan biologi.

\section{HASIL PENELITIAN DAN PEMBAHASAN}

Hasil kajian pustaka menunjukkan bahwa upaya integrasi dan islamisasi ilmu pengetahuan yang telah dilakukan oleh para pakar, baik dalam tataran konsep atau aplikatif. Dalam tataran aplikatif diantaranya dikembangan di 4 perguruan tinggi islam di indonesia yaitu: Konsep Pohon IImu UIN Maulana Malik Ibrahim Malang oleh Imam Suprayogo (2005), konsep jaring laba-laba UIN Sunan Kalijaga Yogyakarta: Paradigma Integrasi-Interkoneksi oleh Amin Abdullah (2006), Konsep Menara Kembar tersambung (Integrated Twin Tower) UIN Sunan Ampel Surabaya (Syaifuddin, 2013), dan Konsep Wahyu Memandu IImu UIN Sunan Gunungjati Bandung (Athoilallah dan Irawan, 2016).

Dari berbagai macam merek atau label yang ada dalam upaya integrasi ilmu islam dan sains diatas sesungguhnya memiliki core atau muatan yang sama dalam memandang integrasi itu sendiri. Yaitu keinginan dan spirit yang sama untuk menunjukkan adanya interrelasi, interkoneksi dan sinergi berbagai bidang dan disiplin ilmu. Tujuannya adalah membangun paradigma keilmuan yang saling mendekat dan menunjang. Sehingga pada akhirnya nanti dapat terwujud pemahaman keilmuan yang lebih holistik atau menyeluruh.

Upaya pendekatan dan integrasi antar kelimuan yang telah dipaparkan dalam uraian diatas lebih mengarah pada aspek metodologis-filosofis, yang tentunya masih sangat umum atau general dalam berbagai bidang keilmuan. Tentu dalam tataran aplikatif masih dibutuhkan pendekatan model baru yang lebih praktis dan mudah dicerna, khususnya bagi pelajar atau mahasiswa. Hal itu mendorong penulis untuk menawarkan atau merekomendasikan model pendekatan integrasi islam dan biologi, yaitu model "Segitiga IImu" (lihat gambar 2) sebagai kunci tadabbur Al-Qur'an dalam bidang Biologi.

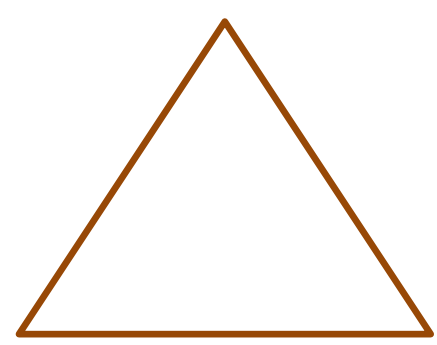

Gambar 2. Segitiga IImu

Segitiga Ilmu itu mencakup; Al-Qur'an sebagai inspirasi, konfirmasi dan dogmaempiris. Adapun uraian dan aplikasi dari ketiga model adalah sebagaimana berikut;

\section{Model Integrasi Al-Qur'an sebagai Payung (Sumber Inspirasi) dalam Pembelajaran Biologi}

Seringkali orang mengemukakan bahwa Sains seperti Biologi adalah sebagai pembukti kebenaran ayat Al-Qur'an. Pernyataan ini sebenarnya berbahaya, sebab apabila ternyata melalui penelitian Biologi atau Sains menghasilkan ketidakterbuktian, 
maka yang terjadi adalah membuat kesimpulan bahwasannya Al-Qur'an itu keliru karena tidak ilmiah dan tidak terbukti kebenarannya. Padahal sebenarnya adalah bisa jadi ilmu yang terbatas, sehingga sains tidak menjangkau apa yang dikemukakan dalam Al-Qur'an. Oleh karena itu pernyataan bahwa Sains adalah Pembukti Al-Qur'an haruslah diralat dengan Sains Adalah Penjelas Al-Qur'an. Jadi kedudukannya hanya sebagai penjelas apa yang ada dalam Al-Qur'an.

Sebagai sumber inspirasi, dalam model pendekatan ini, Al-Qur'an harus diletakkan di awal dalam kajian, dan bukan diposisikan sebagai pembenar pernyataan dalam Sains. Sehingga integrasi instan yaitu dengan menempel-nempelkan ayat AlQur'an ke dalam penjelasan Sains akan dihindari. Beberapa uraian berikut menjelaskan hal ini.

a. Al-Qur'an Surat Ali Imron 191 sebagai Sumber Inspirasi Lahirnya Hukum Struktur Mengikuti Fungsi dalam Biologi

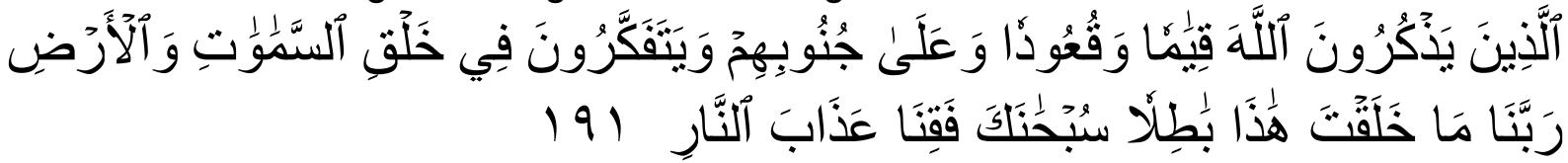

Artinya: (yaitu) orang-orang yang mengingat Allah sambil berdiri atau duduk atau dalam keadan berbaring dan mereka memikirkan tentang penciptaan langit dan bumi (seraya berkata): "Ya Tuhan Kami, Tiadalah Engkau menciptakan ini dengan sia-sia, Maha suci Engkau, Maka peliharalah Kami dari siksa neraka.

Satu di antara hukum dalam Biologi adalah Hukum Struktur Mengikuti Fungsi, yang intinya tidak ada struktur dalam makhluk hidup yang tidak memiliki fungsi. Suatu struktur tidak perlu ada dalam makhluk hidup kalau memang tidak ada fungsinya. Dengan demikian maka tidak ada struktur yang tidak memiliki fungsi yang jelas. Sebagai contoh ekor hewan antara lain sebagai alat keseimbangan. Sedangkan manusia tidak perlu lagi ekor, karena sudah seimbang dan berdiri tegak (Gambar 3). Demikian pula bentuk paruh dan kaki burung tidak pernah terlepas dari fungsinya. Paruh burung pemakan daging berbeda dengan paruh burung pemakan ikan atau serangga (Gambar 4). Kaki unggas yang sering hidup di perairan seperti itik misalnya memiliki selaput renang yang berguna sebagai bidang sentuh yang dengan luasnya tersebut dapat memperkecil tekanan oleh kaki. Kaki burung predator juga memiliki ciri khas (Gambar 5).

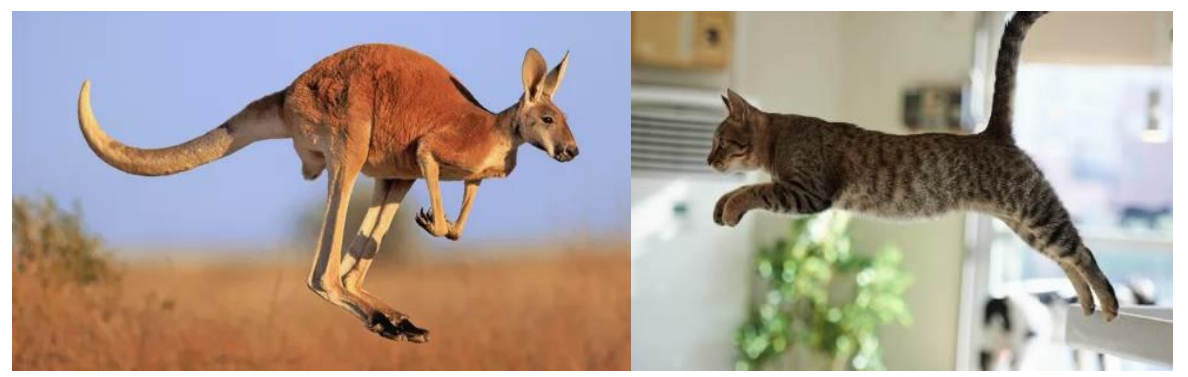

Gambar 3. Kanguru (sumber: www.thoughtco.com) dan Kucing (https://www.idntimes.com) sebagai Alat Keseimbangan 


\begin{tabular}{|c|c|c|c|c|c|c|}
\hline $\begin{array}{c}\text { Bentuk } \\
\text { paruh }\end{array}$ & Pemakan biji & $\begin{array}{l}\text { Pemakan } \\
\text { daging }\end{array}$ & $\begin{array}{l}\text { Mencari } \\
\text { makan di } \\
\text { lumpur }\end{array}$ & $\begin{array}{l}\text { Pemakan } \\
\text { serangga }\end{array}$ & Pemakan ikan & $\begin{array}{l}\text { Penghisap } \\
\text { madu }\end{array}$ \\
\hline Ciri & $\begin{array}{l}\text { pendek, } \\
\text { kuat }\end{array}$ & $\begin{array}{l}\text { kuat, } \\
\text { tajam, } \\
\text { melengkung } \\
\text { di ujung }\end{array}$ & $\begin{array}{l}\text { seperti } \\
\text { sudu, } \\
\text { pangkal } \\
\text { bergerigi }\end{array}$ & $\begin{array}{l}\text { kuat, } \\
\text { agak } \\
\text { panjang, } \\
\text { runcing }\end{array}$ & $\begin{array}{l}\text { panjang, } \\
\text { berkantong }\end{array}$ & $\begin{array}{l}\text { panjang, } \\
\text { runcing }\end{array}$ \\
\hline Contoh & pipit & elang & bebek & pelatuk & pelikan & kolibri \\
\hline
\end{tabular}

Gambar 4. Berbagai Bentuk Paruh Sesuai Fungsi (sumber: www.brainly.com)

\begin{tabular}{|l|l|l|l|} 
No. Bentuk Kaki & \multicolumn{2}{|c|}{ Ciri-Ciri } \\
\hline 1 & Burung & $\begin{array}{l}\text { Memiliki tiga jari menghadap ke } \\
\text { depan dan satu jari bagian } \\
\text { belakang todak tumbuh sempurna. }\end{array}$ & $\begin{array}{l}\text { Ayam dan } \\
\text { burung unta. }\end{array}$ \\
\hline 2 & Jari kaki berselaput. & Itik dan angsa. \\
\hline 3 & Perenang & $\begin{array}{l}\text { Jari kaki pendek, kuku } \\
\text { melengkung tajam, dan cakar } \\
\text { kuat untuk mencengkeram. }\end{array}$ & $\begin{array}{l}\text { Burung elang } \\
\text { dan rajawali. }\end{array}$ \\
\hline 4 & Pemangsa & $\begin{array}{l}\text { Jari terdiri atas empat, dengan } \\
\text { dua jariberada didepan dan dua } \\
\text { jari lainya berada di belakang. }\end{array}$ & Burung pelatuk. \\
\hline 5 & Pemanjat & $\begin{array}{l}\text { Jari kaki panjang dan telapak } \\
\text { kakinya datar untuk bertengger } \\
\text { di ranting-ranting pohon. }\end{array}$ & $\begin{array}{l}\text { Kutilang dan } \\
\text { kenari. }\end{array}$ \\
\hline
\end{tabular}

Gambar 5. Berbagai Bentuk Kaki Aves (sumber: www.brainly.com)

Sangat banyak fenomena dalam Biologi yang bersumber dari Al-Qur'an Surat Ali Imran 191 yang bukan hanya berbagai hal yang berhubungan dengan morfologi, namun juga fisiologi antara lain:

(1) Enzim-enzim pencernaan dalam hewan karnivora, sangat dominan dengan enzim proteolitik dibandingkan dengan hewan Herbivora.

(2) Reaksi fiksasi karbon dalam proses Fotosintesis dikatalisis oleh enzim yang disebut Rubisco, protein yang sangat melimpah pada tanaman. Enzim Rubisco tidak ada pada hewan karena kalau ada tidak akan ada gunanya karena hewan tidak berfotosintesis.

b. Al-Qur'an Surat Al-Qomar 49 dan Al Furqan ayat 2 sebagai Sumber Inspirasi yang melengkapi lahirnya Hukum Struktur Mengikuti Fungsi dalam Biologi

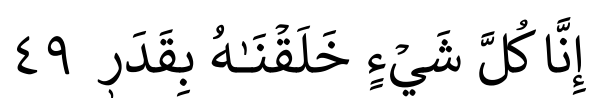

Artinya: Sesungguhnya Kami menciptakan segala sesuatu ménurut ukurañ (QS: AlQomar: 49)

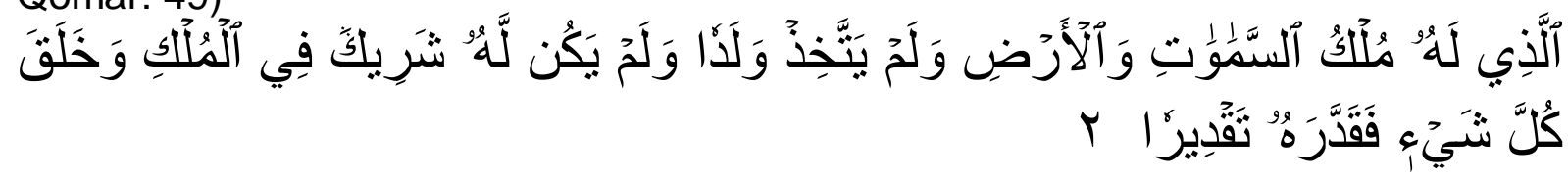

Artinya : yang kepunyaan-Nya-lah kerajaan langit dan bumi, dan Dia tidak mempunyai anak, dan tidak ada sekutu bagi-Nya dalam kekuasaan(Nya), dan dia telah 
menciptakan segala sesuatu, dan Dia menetapkan ukuran-ukurannya dengan serapirapinya (QS. Al Furqan: 2)

Segala ciptaan Allah S.W.T selalu proporsional, terstrukkur rapi, dan dalam kapasitas yang tepat sesuai dengan fungsinya. Sebagai contoh adalah dalam Biologi Sel pada saat mempelajari Mitokondria (suatu organel dalam sel yang berperan menghasilkan energi), memiliki membran dalam berlipat-lipat yang disebut Krista sebagai tempat Electron Transport System bagian akhir dari Respirasi (proses produksi energi) dengan kerapatan kelipatan yang berbeda-beda, tergantung kepada jumlah kebutuhan energi jenis-jenis sel. Kerapatan krista pada mitokondria sel otot jantung atau sel penyusun sayap serangga akan berbeda dengan krista pada mitokondria sel penyusun tulang (Gambar 6).

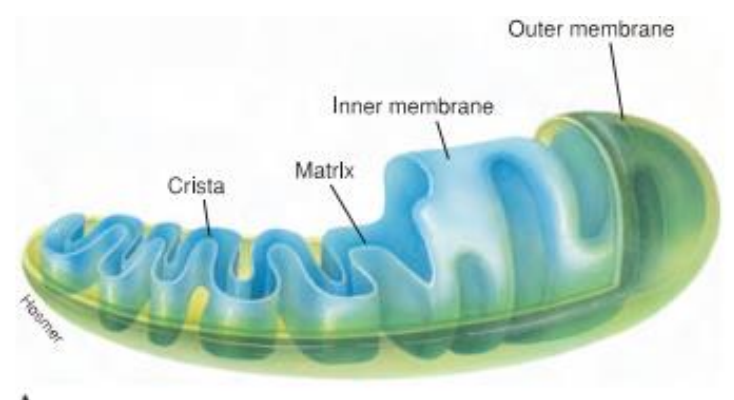

A

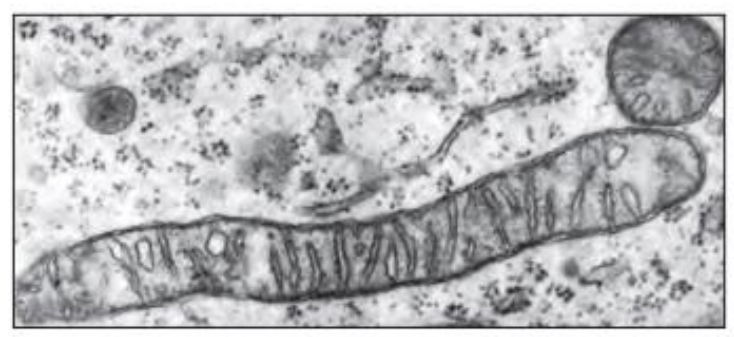

Gambar 6. A. Krista pada Organel Mitokondria sebagai Pusat Produksi Energi Sel B. Penampakan Mitokondria dari mikroskop elektron perbesaran 30.000x (Hickman, Robert and Larson, 2001)

Demikian pula letak mitokondria (sebagai Power) pada sel spermatozoa, berada pada bagian yang paling ideal untuk menghasilkan gerakan spermatozoa maju (progresif) menuju ovum (Gambar 7).

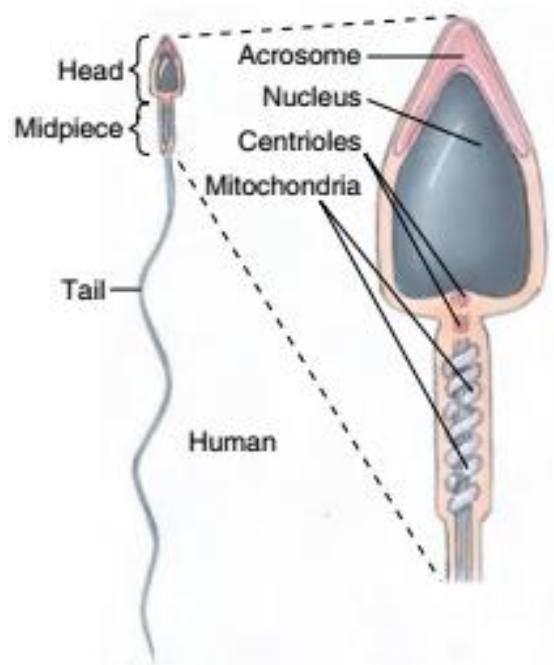

Gambar 7. Struktur Spermatozoa dengan Mitokondria pada Bagian Leher (Sumber: Hickman, Robert and Larson, 2001) 
Contoh lain fenomena dalam Biologi yang bernaung dari Q.S. Al-Qomar 49 adalah fenomena oogenesis (pembentukan ovum) pada wanita. Seharusnya yang diovulasi setiap bulan adalah 4 buah, namun Allah s.w.t mengaturnya menjadi 1 saja ovum yang fungsional, sedangkan yang 3 tidak fungsional dan mereduksi menjadi badan kutub (polosit) atau polar bodies (Gambar 8). Seandainya 4 ovum selalu fungsional, maka setiap melahirkan akan berisi 4 bayi. Di sisi lain spermatozoa pada laki-laki, sekali ejakulasi dihasilkan jutaan spermatozoa, karena untuk antisipasi banyaknya spermatozoa yang berguguran pada saat perjalanan menemui ovum.

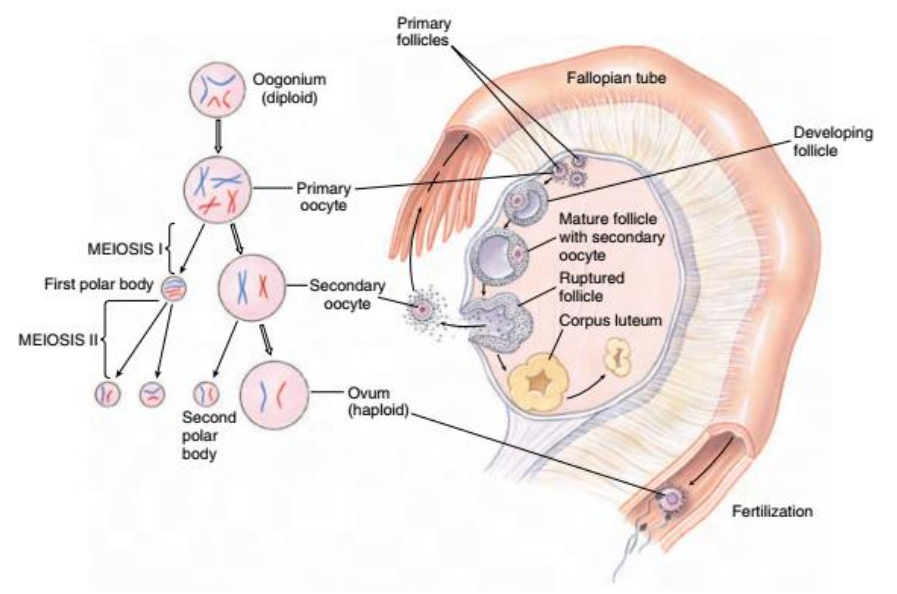

Gambar 8. Proses Oogenesis dengan Produk 1 (Satu) Buah Ovum dan 3 Badan Kutub yang Mereduksi atau Tidak Fungsional (Sumber: Hickman, Robert and Larson, 2001)

c. Al-Qur'an Surat Ar-Rahman (5-10) dan Al-Mulk (3-4) sebagai Sumber Inspirasi atau Kaidah Utama Keseimbangan Alam

Al-Qur'an Surat Ar-Rahman 5-10 dan Al-Mulk ayat 3-4 merupakan Kaidah Utama Keseimbangan dalam Ekologi dan sistem penciptaan alam. Oleh karena itu, pada saat pembelajaran, khususnya Ekologi, ayat ini sangat penting dikaji pada awal atau pembuka perkuliahan. Pembahasan ayat ini dapat dihubungkan dengan masalah keseimbangan ekosistem, yakni suatu kondisi dimana interaksi antara komponenkomponen di alam berlangsung secara harmonis dan seimbang.Keseimbangan di dalam organisme dan ekosistem berdampak signifikan pada keselerasan makhluk hidup itu sendiri serta kesejahteraan hidup manusia dan mahluk hidup lainnya. Keselarasan ini tidak hanya terjadi di tingkat atom hingga ekosistem bahkan alam semesta.

Allah berfirman:

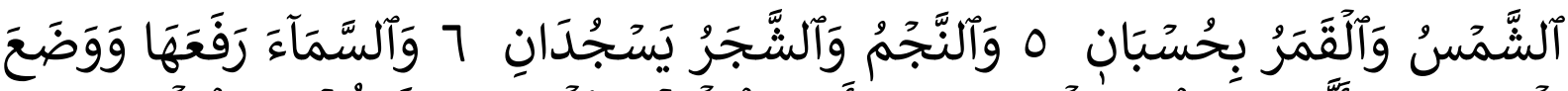

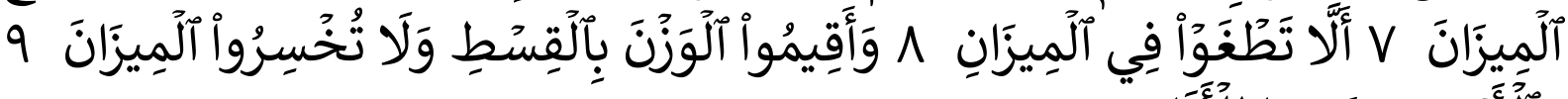

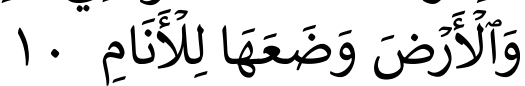

Artinya: Matahari dan bulan (beredar) menurut perhitungan. Dan tumbuh-tumbuhan dan pohon-pohonan kedua-duanya tunduk kepada-Nya. Dan Allah telah meninggikan langit dan Dia meletakkan neraca (keadilan-agar seimbang). Supaya kamu jangan melampaui batas tentang neraca (keseimbangan) itu. Dan tegakkanlah timbangan 
itu dengan adil dan janganlah kamu mengurangi neraca itu. Dan Allah telah meratakan bumi untuk makhluk(Nya) (QS: Ar-Rahman 5-10)

Demikian juga firmanNya dalam Q.S. Al-Mulk ayat 3-4;

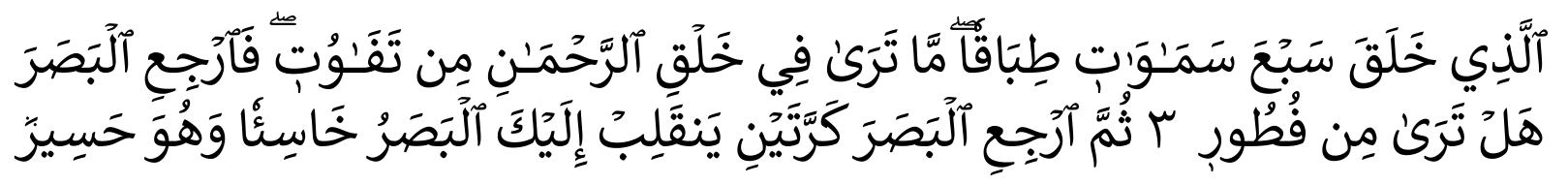

Artinya: Yang telah menciptakan tujuh langit berlapis-lapis. kamu sekali-kali tidak melihat pada ciptaan Tuhan yang Maha Pemurah sesuatu yang tidak seimbang. Maka lihatlah berulang-ulang, Adakah kamu Lihat sesuatu yang tidak seimbang? Kemudian pandanglah sekali lagi niscaya penglihatanmu akan kembali kepadamu dengan tidak menemukan sesuatu cacat dan penglihatanmu itupun dalam Keadaan payah.

\section{Model Integrasi Al-Qur'an sebagai Sumber Konfirmasi dalam Pembelajaran Biologi}

Pada model ini, setelah pada awal pembelajaran Al-Qur'an ditempatkan sebagai payung atau sumber inspirasi yang menaungi berbagai fenomena dalam Biologi, maka pada model ini pembahasan dalam suatu temuan dalam Biologi atau riset Biologi, "dikembalikan" atau dikonfirmasikan dengan Al-Qur'an. Dengan demikian, analisis dan sintesis dalam Biologi, tidak pernah lepas dengan apa yang sudah terwahyukan dalam AI-Qur'an.

Sebagai contoh adalah perolehan data tentang Trikoma (rambut pada epidermis daun, misal daun kedelai) yang memiliki kerapatan berbeda-beda (Gambar 9). Daun yang memiliki kerapatan trikoma tinggi, maka akan memiliki ketahanan yang tinggi terhadap serangan hama ulat grayak (Spodoptera sp.) (Gambar 10) dibandingkan dengan daun dengan kerapatan trikoma rendah. Bagaimana seandainya Allah s.w.t menciptakan semua daun kedelai dengan kerapatan trikoma semuanya tinggi? Maka dapat dipastikan tidak ada ulat grayak yang dapat hidup karena semuanya tidak dapat makan akibat terganggu oleh Trikoma. Sebaliknya apabila semua daun kedelai memiliki Trikoma dengan kerapatan rendah, maka habislah semua daun kedelai oleh ulat grayak. Berdasarkan perolehan data ini, kemudian dilakukan analisis hubungan dengan Q.S. Al-Mulk ayat 3-4 atau ayat Qur'an yang lainnya. Inilah model integrasi dengan konfirmasi ("dikembalikan") kepada AlQur'an.

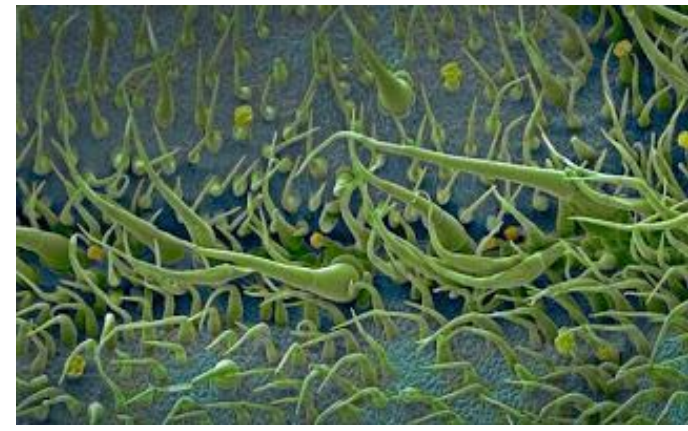

Gambar 9.Trikoma pada Epidermis Daun (Sumber: www.quipper.co.id) 


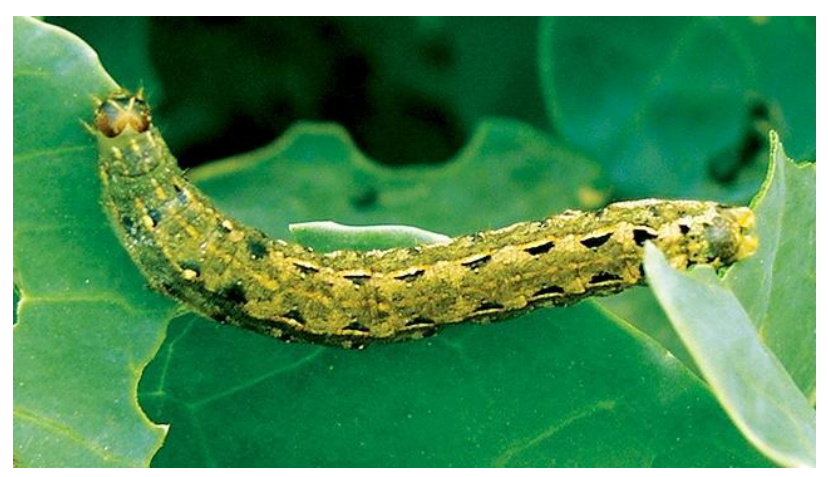

Gambar 10. Ulat Grayak (Spodoptera litura) (Sumber: www.greeners.co)

Perbedaan yang dimiliki daun kedelai dalam hal kerapatan trikoma, mengisyaratkan kepada hadits (walaupun lemah) yakni perbedaan itu adalah rahmat, dengan berbeda ini dapat digunakan untuk melakukan seleksi galur kedelai yang akan ditanam sekaligus sebagai tindakan pengendalian hayati.

\section{Model Integrasi Al-Qur'an sebagai sumber Deskripsi-Referensi yang akurat}

Al-Qur'an sebagai sumber deskripsi-referensi adalah pendekatan pemahaman Al-Qur'an dengan ilmu pengetahuan yang terus berkembang. Setiap masa akan terus lahir teori-terori baru sesuai dengan kemajuan zaman. Secanggih apapun temuan itu pasti akan tetap memiliki celah dalam akurasi kebenarannya. Celah dalam temuan ilmiah itu dikarenakan belum finalnya teori tersebut atau kurangnya informasi yang memadai sehingga temuan ilmiah masih menyisakan pertanyaan. Al Quran hadir untuk menuntun dan menjelaskan temuan ilmiah itu dengan lebih gamblang dengan sangat akurat. Inilah yang kami sebut bahwa Al-Qur'an bisa menjadi DeskripsiReferensi penemuan ilmiah dimasa yang akan datang. Tentu saja penjelasan disini sifatnya tidak detail. Al-Quran sering menjelaskan penjelasan ilmiah dengan simbolsimbol dan analogi yang paling mendekati dan mudah dicerna oleh akal manusia dari berbagai latar belakang keilmuan. Justru dengan simbol-simbol itulah seharusnya memicu manusia untuk terus berfikir dan merenung.Di antara ayat yang berbicara tentang hal tersebut adalah firman Allah;

a. Segala Sesuatu diciptakan berpasangan; Surat Yasin 36 ayat 36 dan AdzDzariyat (51):49

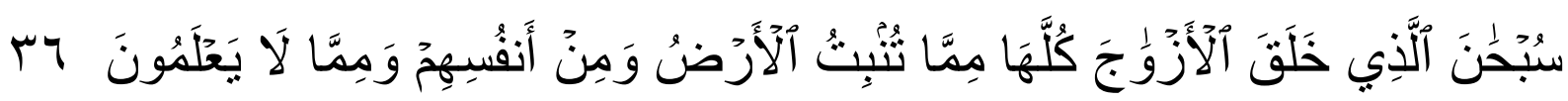

Artinya: Maha Suci Tuhan yang telah menciptakan pasangan-pasangan semuanya, baik dari apa yang ditumbuhkan oleh bumi dan dari diri mereka maupun dari apa yang tidak mereka ketahui (Yasin 36 ayat 36)

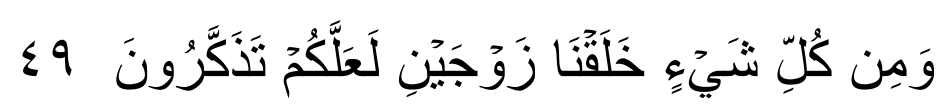

Artinya: Dan segala sesuatu Kami ciptakan berpasang-pasangan supaya kamu mengingat kebesaran Allah (Adz-Dzariyat (51):49) 
Ayat diatas menegaskan bahwa segala ciptaan Allah berpasangan, 'Pasangan' yang diindikasikan ada 3 macam, yaitu tumbuhan (apa-apa yang hidup di bumi), manusia dan apa-apa yang tidak atau belum diketahui manusia. Frase: "apa yang tidak mereka ketahui" menunjukkan bahwa akan ada penemuan-penemun lanjutan dan banyak hal yang nantinya terus menjadi misteri. Sebagaimana disebutkan: dalam menafsirkan ayat diatas: Mahasuci Allah lagi Mahatinggi yang telah menciptakan berbagai jenis tanaman dan buah-buahan, yang telah menciptakan manusia laki-laki dan perempuan dan yang telah menciptakan makhluk-makhluk lainnya yang tidak manusia ketahui di darat, laut dan lainnya. (https://tafsirweb.com/7992-quran-suratyasin-ayat-36.htm)

Dalam kasus tanaman misalnya: ada tanaman yang bereproduksi seksual atau seksual, generatif atau vegetatif, ada spesies tumbuhan dioecious artinya, organ jantan dan betina ditemukan pada tanaman terpisah. Ada juga spesies monoecious di baik organ jantan maupun betina ditemukan pada tumbuhan yang sama. Meskipun sebagian besar tanaman bereproduksi secara seksual, ada juga yang spesies yang berkembang biak dengan cara aseksual. Misalnya lumut dan pakis berkembang biak melalui spora. Oleh karena itu Alquran meenggunakan kata pilihan "berpasangan" tidak selalu dalam konteks reproduksi, namun juga dalam konteks yang lain. Selanjutnya implikasi dari wahyu Al-Quran tidak terbatas pada tanaman saja; itu mencakup segalanya yang diciptakan Allah. Pada Hewan; jantan-betina, habitat airdarat, sperma-ovum, spermatozoa $x$ dan y (lihat gambar 11) dan masih banyak lagi. Bahkan benda mati, keberadaan 'pasangan' diantaranya; panas-dingin, basah-kering, materi-nonmateri, elektron-positron dan lainnya.

Bagaimanapun juga para ilmuwan masih membutuhkan lebih banyak informasi ilmiah untuk memahami dengan jelas implikasi dari wahyu penciptaan benda-benda yang berpasangan dan makhluk hidup yang belum diketahui oleh manusia. Kemajuan ilmu pengetahuan akan memberikan jawabannya di masa depan.

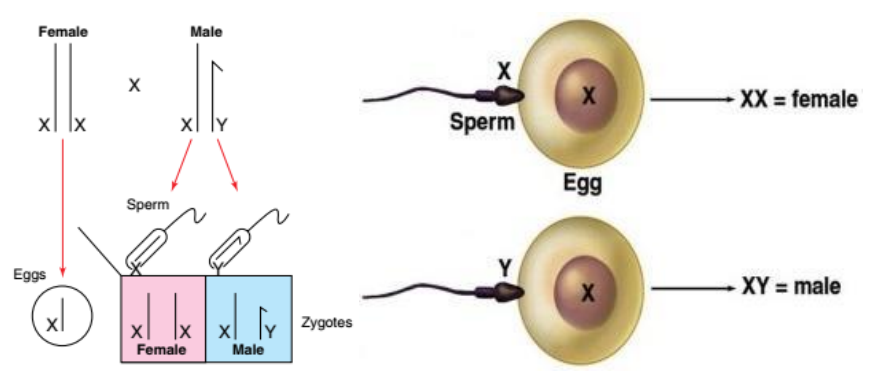

Gambar 11. Spermatozoa membawa kromosom x dan y, sebagai penentu jenis kelamin embrio (Sumber: Hickman, Robert, dan Larson, 2001)

\section{b. Distribusi organișme ekstraterestrial (diluar bumi)}

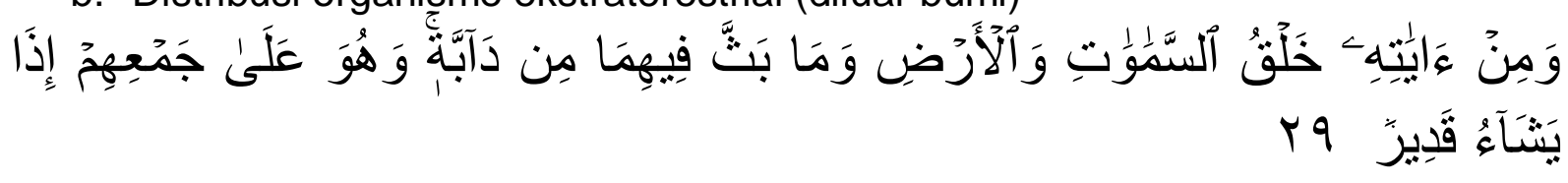


Artinya: Di antara (ayat-ayat) tanda-tanda-Nya ialah menciptakan langit dan bumi dan makhluk-makhluk yang melata Yang Dia sebarkan pada keduanya. Dan Dia Maha Kuasa mengumpulkan semuanya apabila dikehendaki-Nya (Asyura: 29)

Berdasarkan ayat diatas, Allah hendak memberi tahu kita tentang penciptaan dan distribusi organisme yang tidak hanya di bumi tetapi juga di daerah lain diluar bumi. Kata "Dabbah" menurut tafsir muyassar: secara tekstual ayat ini menjelaskan bahwa Allah menciptakan pula makhluk-makhluk melata di langit, bisa jadi terdapat sebagian planet yang dapat dihuni oleh makhluk hidup] (Referensi: https://tafsirweb.com/9119-quran-surat-asy-syura-ayat-29.html)

Explorasi di masa yang akan datang akan membuktikan bahwa kehidupan tidak hanya di bumi namun juga di planet lain, walaupun hingga saat ini belum ada bukti yang ilmiah ditemukannya kehidupan di planet lain, dari kacamata keimanan sudah dapat dipastikan dengen deskripsi dan referensi dari Al-Qur'an bahwa kehidupan diluar bumi benar adanya, wktu yang akan menjawab seiring dengan perkembangan ilmu pengetahuan.

C. Munculnya organisme khusus di Bumi

Al-Quran memberi tahu kita tentang kurangnya kepercayaan orang-orang kepada $\mathrm{Al}$ Qur'an (tidak beriman kepadaNya) sehingga Allah telah menetapkan untuk memunculkan/mengutus organisme khusus yang akan mengingatkan umat manusia tentang fakta ini sebagaimana firmanNya;

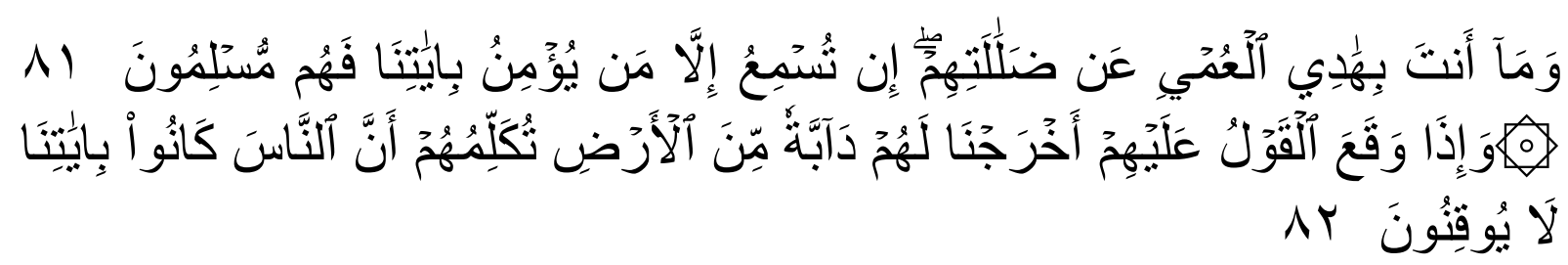

Artinya: Dan kamu (Muhammad) sekali-kali tidak dapat memimpin (memalingkan) orang-orang buta dari kesesatan mereka. Kamu tidak dapat menjadikan (seorangpun) mendengar, kecuali orang-orang yang beriman kepada ayat-ayat Kami, lalu mereka berserah diri. Dan apabila perkataan telah jatuh atas mereka, Kami keluarkan sejenis binatang melata dari bumi yang akan mengatakan kepada mereka, bahwa sesungguhnya manusia dahulu tidak yakin kepada ayat-ayat Kami (An Naml [27]:8182)

Keluarnya binatang melata yang dapat berbicara dengan manusia merupakan salah satu di antara tanda-tanda kiamat. Mereka tidak beriman kepada Al Qur'an yang menerangkan tentang kebangkitan, hisab dan pembalasan. Oleh karena lemahnya ilmu dan keyakinan mereka kepada ayat-ayat Allah, maka Allah mengeluarkan binatang melata tersebut yang merupakan ayat-ayat Allah yang menakjubkan untuk menerangkan kepada manusia apa yang mereka perselisihkan (Referensi: https://tafsirweb.com/6946-quran-surat-an-naml-ayat-82.html) Insya Allah dengan kemajuan ilmu yang lebih tinggi lagi, implikasi dari ayat-ayat ini juga akan menjadi jelas. Inilah model ketiga yang disebut bahwa Al-Qur'an sebagai Dogma-Empiris. 


\section{SIMPULAN DAN SARAN}

Integrasi Sains-Islam dalam pembelajaran Biologi dapat dilakukan dengan tiga macam model yakni: Model Integrasi Al-Qur'an sebagai Sumber Inspirasi, yakni meletakkan Al-Qur'an pada awal pembelajaran sebagai payung pengetahuan atau sumber inspirasi ilmu pengetahuan atau sumber rujukan utama yang selanjutnya dijelaskan oleh berbagai fenomena dalam sains. Kedua Model Integrasi Al-Qur'an sebagai Sumber Konfirmasi, yakni melakukan analisis kritis/pembahasan fenomena dalam sains, yang kemudian dikonfirmasikan dengan Al;-Qur'an, dalam arti temuan dalam sains adalah memperjelas apa yang telah dikermukakan Al-Qur'an. Ketiga; Model Integrasi Al-Qur'an sebagai Sumber Dogma-Empiris, untuk melihat misteri masa depan sains di masa yang akan datang, dimana manusia belum mampu menemukan penjelasan secara empirik tanpa dibimbing wahyu (Al-Qur'an). Ketiga model dapat digunakan secara simultan dan bersinergi dalam pembelajaran Biologi. Disarankan untuk dilakukan pemetaan dan klasifikasi ayat-ayat terkait dengan cabangcabang ilmu biologi sehingga lebih memudahkan lagi dalam implementasi pengajaran dan integrasi.

\section{RUJUKAN}

Abdullah, M. Amin. (2006). Islamic Studies Di Perguruan Tinggi: Pendekatan IntegratifInterkonektif, Cet. ke-1. Yogyakarta: Penerbit Pustaka Pelajar.

Ashtankar, O. M. (2016). Islamic perspectives on environmental protection. 2(1), 438441.

Athoilah, MA dan Irawan (2016). Trilogi Wahyu Memandu IImu. http://isc.uinsgd.ac.id/wp-content/uploads/2018/12/Trilogi-Wahyu-MemanduIlmu.pdf

Faishal (2018). Integrasi IImu dalam Pendidikan. Ta"dibi: Jurnal Prodi Manajemen Pendidikan Islam Volume VI Nomor 2 Th 2018

Fajari, I. A. (2016). Klasifikasi IImu Pengetahuan Menurut Imām Al-Ghazālī. Kontemplasi: Jurnal Ulmu-Ilmu Ushuluddin, 4(2). https://doi.org/10.21274/kontem.2016.4.2.299-316

Faruqi, Y. M. (2006). Contributions of Islamic scholars to the scientific enterprise. International Education Journal 7(4), 391-399.

Hickman, C.P., Robert, L.S., and Larson, A. (2001). Integrated Principles of Zoology. Edisi 11. McGrawHill

Hidayat, M. (2014). Pendekatan integratif-interkonektif: tinjauan paradigmatik dan implementatif dalam pembelajaran pendidikan agama islam. TA'DIB, Vol. XIX, No. 02, Edisi November 2014. XIX (02), 276-287.

Hussain, A. (2019). Qur 'an and Science: A Study of the Compatibility of Qur'anic Verses With Modern Scientific Theories. 2(2), 42-50. DOI: https://doi.org/10.31943/afkar_journal.v4i1.53

Kettani, M.A. (1976) Moslem contributions to the natural sciences. Impact of Science on Society, 26(3), 135-147.

Malik, A. H., Ziermann, J. M., \& Diogo, R. (2018). An untold story in biology: the historical continuity of evolutionary ideas of Muslim scholars from the 8th century to Darwin's time. Journal of Biological Education, 52(1), 3-17. https://doi.org/10.1080/00219266.2016.1268190 
Mufid, (2013), Integrasi IImu-IImu Islam. Equelibrium: Sekolah Tinggi Agama Islam Negeri (STAIN) Kudus, Indonesia Volume 1, No.1, Juni 2013

Qutub, S. (2011). Sumber-Sumber IImu Pengetahuan Dalam Al Qur'an Dan Hadits. Humaniora, 2(9), 1339-1350.

Sarton, G. (1927). Introduction to the History of Science, Volume 1. Washington: Carnegie Institution of Washington

Suprayogo, I (2005). Membangun Integrasi IImu dan Agama: Pengalaman UIN Malang. Zainal Abidin Bagir (ed)., Integrasi Ilmu dan Agama: Interpretasi dan Aksi, Bandung: Mizan, 2005

Suryaningsih, Y. (2018). Penerapan Pembelajaran Biologi Berbasis Al-Qur'an Sebagai Metode Untuk Pembentukan Karakter Siswa. Jurnal Bio Educatio, Volume 3, Nomor 1, April 2018, hlm. 22-33 ISSN: 2541-2280

Syaifuddin (2013). Integrated Twin Towers dan Islamisasi IImu. Jurnal PAI Vol No1 Mei 2013. Hal 2-20

Wahid, P. A. (2018). From Genomics to Biomemetics : The Quran rewrites biology The Quran rewrites biology. March, 76.

Wahid, P.A. (2016). The Quran: Scientific Exegesis, www.islamicscience.in, Adam Publishers and Distributors, New Delhi

Zain, Z., \& Vebrianto, R. (2017). Integrasi Keilmuan Sains Dan Islam Dalam Proses Pembelajaran Rumpun IPA. 18-19. 